\title{
Escolas de Arte - Devires Floresta: zonas de confluências antropofágicas
}

\author{
Apenas brasileiros de nossa época. Tudo digerido. Sem meeting cultural. \\ Experimentais. Poetas... Bárbaros, crédulos, pitorescos e meigos... A floresta e a escola. \\ O Museu Nacional. A cozinha, o minério e a dança. A vegetação. Pau-Brasil. \\ - Oswald de Andrade (Poesia Pau-Brasil. CorréodaMrhã 18/3/1924)
}

Este dossiê se dirige @s agentes - pesquisador@s, curadores, artistas e educador@s que atuam e refletem sobre as mudanças em jogo no sentido público da arte, que por sua vez se desloca de sua própria centralidade para dar lugar e ser participante da virada social para além de sua desmaterialização enquanto objeto-estético, mas para um acontecer solidário e multissensorial. Enquanto isso, as escolas públicas, com ou sem arte, se alinham com as lutas emergenciais voltadas à resistência e aos ativismos coletivos, movimentos sociais contra os impactos políticos, econômicos e ambientais dos regimes neoliberais. Daí, o que se aborda aqui como "devir floresta" sem dúvida remete à antropofagia utópica e poética de Oswald de Andrade, mas não apenas como um mito ou pathos, mas como ativação de confluências de opostos que atravessam a história do Brasil. 
Em especial, é nas ruas, escolas e universidades públicas (de educação para artistas e cidadãos não artistas) também frágeis e precárias, que mesmo operando entre gaiolas de pedagogias de controle funcionalista e estéticas ainda individualistas e colonizadoras, que as asas de invenções e rupturas epistêmicas enunciam e conclamam para posicionamentos pragmáticos de marchas decoloniais das utopias antropofágicas inacabadas.

Agradecemos a especial colaboração de vári@s artistas, pesquisador@s e praticantes de viradas estéticas, éticas e políticas da arte e educação. Em especial a Luiz Sérgio de Oliveira e ao grupo de pesquisa Interfluxos Experimentais Contemporâneos Arte e Sociedade (Daniela Moreira, Gabriela Bandeira, Rebeca Machado e Nathalia Christine da Silva), que não mediram esforços para realizar e transcrever as entrevistas reunidas neste dossiê. Tem-se como zonas de confluências antropofágicas um interesse de articular, através de diferentes vozes e experiências, o devir floresta que desafia a formação e a educação não apenas de artistas, mas os agenciamentos de resistência e transformação social. Na verdade, não existe uma ordem e categorias a priori para estes artigos, mas, na medida em que eles foram sendo recolhidos e relidos, percebem-se ressonâncias e sinergias proximais, assim como emaranhamentos e conexões imprevisíveis. Dessa maneira, um primeiro engajamento e deslocamento de zonas de conforto artístico-pedagógico é reunido como fundamentos de emancipação política e poética das Escolas de Floresta e Samba Deixa Falar - Educação Radical. Reúnem-se a genealogia da escola de samba com representantes de uma nova geração pautada pelo agir de encontros de exercícios experimentais de escutas e estados poéticos de subversão e contrapedagogias no diálogo entre Daniela Name, Felipe Ferreira e Jessica Gogan, e nos artigos de Monica Hoff, Rafael Zacca e Fabio Tremonte. Os colapsos civilizatórios e florestas multissensoriais são mobilizadores de práticas artísticas, investigações ancestrais, espirituais e geopoéticas nos trânsitos e viagens de Analu Cunha, Ernesto Neto, Guilherme Vaz (especial homenagem), Jorge Barco, Keyna Eleison e Suzana Queiroga. As Escolas-Florestas de Arte Pública - Outramentos marginais trazem pragmatismos antropofágicos tanto para as instituições acadêmicas quanto para museus de solidariedade onde a educação e a formação do artista alinham

Poiésis, Niterói, v. 20, n. 33, jan./jun. 2019. 
experiências e visões instituintes de outros imaginários marginais - extra-muros e gaiolas, da Barbara Szaniecki, Evanthia Tselika, Livia Flores e Michelle Sommer, Luiz Sérgio de Oliveira e Soledad García Saavedra.

Em todas essas percepções têm-se em comum o reconhecimento de colapsos civilizatórios, o contato com zonas de desconforto ou fronteiras onde o que foi construído por um sistema de valores colonizadores é desmascarado para que se liberem em novas formas de energia e necessidade vital da arte. A arte que então foi pautada pela centralidade do olhar é igualmente questionada - "o olho atrapalha", diz Ernesto Neto. São várias estruturas e pedagogias de ordem e controle que estão sendo transformadas não mais como totens ou templos, mas em plataformas mobilizadoras de reconfigurações de táticas adversas de agir coletivo, contrapedagogias incivilizatórias de escutas dialogais colaborativas.

Nesta escavação entre vozes e entre-vistas, uma arqueologia de futuros inacabados foi sendo também constituída como filosofia floresta para uma escola de arte pública. Entrelaçamentos e Outramentos Incivilizatórios aproximaram as especulações filosóficas do Infinito e Dádiva de Guilherme Vaz, não apenas ao Manifesto Antropofágico de Oswald de Andrade, mas também a Hélio Oiticica, Benedito Nunes e Graça Aranha por um sentido de "alegria cósmica" que nos une como intuição e comunhão diante os colapsos e deslitígio do universo. Devolver a terra à terra, correr para a savana como obra-gênese ainda em processo de nós-outros desterrados nos tristes trópicos, aprendizes e inventores de uma pedagogia da imanência do inacabamento utópico.

Luiz Guilherme Vergara

Poiésis, Niterói, v. 18, n. 30, dez. 2017. 
